\title{
New Light on an Old Friend: Perken's Strange Family Tree
}

\author{
Walter G. Langlois \\ (University of Wyoming-Laramie)
}

As is widely known, most of André Malraux's writings are closely linked to events in his personal life, and his novels in particular contain a number of thinly-veiled autobiographical elements. The most notable among these are to be found in the first half of La Voie royale, an almost factual relation of the author's 1923 incursion into the Cambodian jungle in search of some ancient Khmer ruins. ' Claude Vannec, the hero of that portion of LVR, is obviously closely modeled after Malraux himself. However, the second part of the story--a journey into the territory of the ferocious Moï or jungle savages of the unconquered hinterlands--has no evident links with Malraux's real experiences in Indochina, and the model for the major protagonist of that adventure, Claude's friend Perken, has remained largely a mystery to literary historians. Recently it has become possible to shed a bit of light on the origin and genesis of that character, thanks to the discovery of the first manuscript draft of the novel. The evolution of this literary creation, in turn, illuminates an interesting change that the author made in the orientation of his novel during its gestation period.

First of all, what are the basic elements of the background and early life of Perken as we know them from the text published in 1930, only four years after Malraux's return from Indochina? ${ }^{2}$ Most of the pertinent information is given in one of the early scenes of the book, when an unnamed Armenian gem dealer tells Vannec what he knows about a mysterious stranger who has just boarded the Indochina-bound vessel at Djibouti. Briefly, we learn that the man's name is Perken, that he is of German-Danish origin, and that as a youth of twenty-three he had tried to make his fortune among the savage tribes of the Indochinese jungle by trading costume jewelry for the real but clumsily worked gems and gold ornaments of the natives. We then learn of the subsequent "missions que le Siam lui avait confiées auprès des tribus insoumises, de son organisation du pays shan [au nord-ouest] et des marches laotiennes [au nord-est]"--where each of three fingers of his left hand had been disfigured by "un sillon profond, en spirale, comme un tire-bouchon" (LP, pp. 9, 13). This mutilation was the result of a trial undergone at the hands of the savages. But Perken subsequently tells Vannec that he was ultimately successful in this mission and that he had become "lié, de façon ou d'autre, à presque tous les chefs des tribus libres, jusqu'au

107

LittéRéalité, Vol. I, No. 2, Automne/Fall 1989 
Haut-Laos. Voilà quinze ans que cela dure...[Je voulais créer] une force militaire", he says, "et attendre le conflit inévitable par ici, soit entre colonisateurs et colonisés, soit entre colonisateurs seulement" (LP, p. 60). Unfortunately, according to the Armenian gem dealer, Perken had never known how to use his position of leadership in those regions to make a fortune by dealing in precious stones, and when he urgently needed 200,000 francs to purchase some arms, he had been obliged to go and seek them in Europe--alas, without success. Now he was returning to Siam to undertake another semiofficial mission: the tracking down of a European who had disappeared in the very region of "his" savages, along the Siamese-Tonkin border.

Scholars have long suspected that the final text of LVR was elaborated over a lengthy period of time, a suspicion that was fully confirmed by the recent discovery of the original manuscript of the novel. ${ }^{3}$ In a letter of authentication bound with this lengthy document, Malraux revealed that the first part of the narrative in particular had been extensively reworked during a long gestation period. As he put it: "De ce roman, dont plusieurs versions successives ont été établies l'une sur l'autre, il n'existe de manuscrit complet que celui-ci...[Pour la première section], ces pages sont l'ensemble dont une partie, choisie, constitue les chapitres de la version finale". Indeed, the eighty closely-written pages of material upon which the first major section of the final text is based constitute about one-third of the whole manuscript, and the extensive revisions and reworkings of these pages suggest that Malraux had a certain amount of difficulty in organizing his story, at least in its initial stages, and in deciding where he wanted to go with it. This is very obviously true in the case of the character Perken.

According to the first versions of the manuscript, the novel originally began with a scene in which the narrator, Claude Vannec, and two friends, a Frenchman named Dévy and a Polish fellow named Radke, were on board a ship bound for Indochina. (In subsequent reworkings, Dévy and Radke were combined into the single figure of Radke.) When the vessel makes port at Djibouti, a rather unusual passenger comes aboard. He is an Englishman named Parker, and he is described as follows: "Il avait un profil de consul romain, malgré des cheveux gris taillés en brosse...La gravité et la force du masque romain s'affaiblissaient (quand il se montrait de face), se mêlaient, sans disparaître tout à fait, à un visage blanc et fin de vieille anglaise. 'Cet homme ressemble certainement à sa mère,' dit Claude à Radke."

A few pages later, another passenger--a Ceylonese gem dealer named Pereira, who had long bought stones from the savages of the Indochinese jungles--begins a long recital of what he knows about the life and career of this Englishman, 
whom he calls "un aventurier de nature, ou par défaut de nature". Like many other Europeans, Parker had originally come to Asia to make his fortune as a young man, and like certain of his peers he had not always been particularly concerned to do this in an entirely honorable fashion. He had begun more than twenty-five years earlier as a minor functionary in the judicial branch of the English Foreign Service, assigned to the colony of Ceylon. Not content with his modest stipend, he soon developed a primitive--but for a time successful-scheme for extracting bribes from certain of the wealthy native businessmen who had run afoul of English law. With the help of an accomplice, he simply pretended that he was going to be the judge who would decide the case, and at a secret preliminary meeting--"avec des faux favoris et une perruque" as a disguise--he obtained considerable sums of money with promises of a favorable judgement.

However, continues Pereira, "il n'a pas su partir à temps...Il a eu tort de faire porter sa force à faux, voilà. L'énergie employée à attendre une arrestation, c'est de l'énergie mal employée, n'est-ce pas?" In any case, Parker was arrested, convicted and sentenced to prison for several years. Upon his release, he decided that it would be best to try his luck--and exercise his adventurer's energy--in an area outside the supervision of European law, and so he went to the still independent kingdom of Siam, where he quickly became involved in a new scheme to make his fortune. Again, it was quite simple, but it required both energy and courage. As Pereira described it, Parker went among the wild Shan tribes along the Burmese-Siam border where it was the custom of the natives to wear the raw gemstones found in that area--primarily rubies and sapphires--set in primitive gold chest ornaments, and he convinced the simple tribesmen to exchange their ornaments for the more striking and finished costume jewelry that he brought with him. Of course, to do this, he first had to learn to speak a bit of their language, and to win their confidence. On one occasion, noted Pereira, "pour affirmer une chose avec force, pour donner témoignage...il a brûlé sa main droite sur un brasier shan, devant pas mal de sauvages". As a result of this gesture, that hand had become useless.

When Parker returned to Bangkok from the Shan states in the north a rich man, he changed his name to Davis. His success in working among the tribes in that dissident area had so impressed officials high in the Siamese government that they decided to give Parker an important title: "inspecteur général du Laos siamois", and to send him to organize the tribes in that area in the northeast along the borders of Tonkin. This region was disputed by both the Siamese and the French, and the latter were then consolidating their conquest of all the nonSiamese territories of the peninsula. The situation in these Laotian provinces had 
suddenly become critical, recounted Pereira, because another adventurer, David de Mayrena, had entered the area on a semi-official mission on behalf of the French government, to try and bring the Laotian tribes definitively under French control.

Parker's tentative to confirm Siamese authority in this region was part of the anti-European policy of King Chulalongkorn--the Siamese ruler portrayed in Anna and the King of Siam. This monarch had seen most of the lands surrounding his domains--Burma, Singapore, Cambodia, Cochinchina, Annam and Tonkin--fall to the military power of England or France, and he was determined to counter Europe's aggressive imperialism by every means at his command. ${ }^{4}$ One element in his strategy was to send some two dozen of the most gifted of his sons to various universities and courts abroad, to be educated in Western ways and thus better able to oppose European expansionism. According to Pereira, Parker eventually became indirectly involved in this undertaking as well. The story seems highly improbable.

Chulalongkorn's eldest son and heir to the throne was named Prince Pitsanulok. After several years of study in England, this young man was sent to the court of the Czar, to complete his training at the military academy in Moscow. While there, he met and fell passionately in love with a beautiful young Russian woman, the daughter of a high-ranking army officer. When Pitsanulok indicated that he planned to wed this lady and bring her back to Siam, consular officials in Moscow were very upset and tried forcefully to dissuade him. But in vain. When the married Prince returned to Bangkok, his beautiful and charming wife accompanied him. She soon succeeded in winning the blessing of the King, but the xenophobic old Queen remained adamant in her opposition to the match. This opposition, together with Pitsanulok's subsequent decision to follow Siamese custom and to take another wife, put great strains on the marriage, and finally led to a divorce. After being granted a small pension, the Russian lady left Bangkok and went to seek her fortune in the British colony of Singapore.

Pitsanulok was still very fond of her, continued Pereira, and en route to Europe several months after the divorce, the Prince stopped in Singapore for a brief visit. The meeting with his ex-wife over afternoon tea was cordial, but that evening the Prince complained of violent stomach pains, and by the next morning he was dead. King Chulalongkorn was of course furious, and the Siamese members of Pitsanulok's entourage were almost certain that their master had been poisoned by his ex-wife. However, without any proof, they could not take action against a foreigner who was protected by English law. 
One of the members of the Prince's suite was the Englishman, Parker. Apparently he did not believe in the guilt of the beautiful Russian, to whom he was strongly attracted, and he began to court her assiduously. Before long, she had agreed to marry him. After two years of wedded "bliss" (in which she spent all of his money), the lady left Parker and fled to Shanghai--where she soon became the mistress of a wealthy American businessman. Following the breakup of his marriage, the penniless Parker fled to the Hedjaz, in Saudi Arabia, to attempt to recoup his fortunes, but apparently he was not particularly successful. In any case, when he was subsequently contacted by Siamese officials with the urgent request that he return to Bangkok to undertake an important secret mission on behalf of the government, he accepted; that was how, according to Pereira, he had come to board the vessel for Indochina at Djibouti, his first-class passage paid for by the Siamese. This adventurer with what the French would call "un passé chargé" was the character who eventually became Perken.

In subsequent revisions of this part of the narrative--in which half a dozen closely-written pages of text were cut to three paragraphs--Malraux changed Parker's name to Perken, ultimately combining this character with Radke-Dévy, to become the single Perken of the definitive text. However, as you will recall, a certain number of elements of the fantastic early story of Parker's activities remain in the final version of the novel.

Obviously this text raises several important questions. First of all, how had Malraux come to concoct so fantastic a tale and to create such an improbable background for this personage who was ultimately to become one of the two major figures in this book? Truth is sometimes as strange as fiction, and such is the case in the present instance. For at the time of Malraux's sojourn in Indochina in the mid-1920s, the story of this Englishman's adventures in Siam was apparently one of the scandalous "petites histoires" based on contemporary reality that gossiping French colonists told one another over afternoon tea--or absinth--on the terrace of Saigon's Hôtel Continental. What is even more remarkable than the whole "petite histoire" itself is the fact that some fifty years later all of its major elements were confirmed in the lengthy autobiography by Prince Chakrabongse, the son of Pitsanulok and his Russian wife, and thus a kind of stepson of Parker. ${ }^{5}$ Truth is indeed sometimes stranger than fiction.

However, an even more important question presents itself. What was Malraux's original purpose in creating this extravagant Perken? Where had he originally planned to take his story, and what might have led him to alter so radically its orientation? As is well known, while Malraux was in Indochina in 1924 and 1925, essentially he had two rather different experiences. The first one, his expedition into the jungle in search of Khmer ruins, was a romanesque 
adventure in the tradition of 19th century figures like Sultan Brooke of Sarawak, "Chinese" Gordon, and others. It was this experience that was transformed into the first half of LVR. But this adventure--however vividly it may have touched Malraux and fired his imagination--was basically of very short duration. For most of his two years in Indochina the young man was involved in politics, not adventurism. To be sure, on a primary level this political commitment manifested itself as an effort to oppose the injustice and corruption of those who governed the French possessions on the peninsula. But in a larger sense it related to the whole question of how these lands and peoples in so distant a part of the globe had been brought under the control of European nations like France and England. In short, it involved the manner in which imperialism functioned, and just what the instruments of its conquests were.

Seen in this light, Parker seems to have been originally envisaged by Malraux as the English/Siamese response to the colonizing activities of the Frenchsponsored David de Mayrena. Of course, echoes of this earlier commitment remain in the final version of the story because, as we have seen, Perken organized a federation of the jungle tribes and tried to keep out modern "Western" style civilization, represented by the railroad. This is not at all a gratuitous hypothesis. First of all, we have noted that the original manuscript text specifically indicates that Parker was initially recruited by the Siamese to organize the tribes of Laos and thus to thwart Mayrena's similar efforts on behalf of the French. Secondly, we know from various references and from the lengthy "Règne du malin" text in the original version of the Antimémoires that Malraux was fascinated--one might almost say obsessed--with the figure of David de Mayrena. ${ }^{6}$ When he revised LVR and merged Parker with Radke to form Perken, he added certain traits of character derived from Mayrena, most notably the latter's success in organizing the Moí tribes. In his Antimémoires, Malraux confirms that his Perken had indeed been inspired by the exploits of the adventurer Mayrena, whose activities in the early days of the European conquest of Asia had been so important. As he puts it: "A bien des égards, mon personnage de Perken est né de Mayrena" (A,p.379). However he then adds: "Plus exactement, de ce qui unit Mayrena à un type d'aventurier disparu...Il se confondait avec Brooke, devenu rajah de Sumatra, et quelques-uns de ceux qui osèrent...se rendre sans armes chez les insoumis." Clara Malraux, in her memoirs, confirms--again without furnishing many details--that the lives and exploits of such Westerners who ventured among the Moï or "sauvages insoumis" of the hinterland were indeed frequent subjects of conversation among European colonists, and that her husband had been particularly fascinated by individuals capable of such energy, enterprize, and above all courage. 
Although the Antimémoires contain no specific indications of the names of other adventurers who could claim a place in Perken's family tree, a careful rereading of the definitive text of one scene of LVR in the light of the comments that Malraux made in his autobiography does furnish a valuable clue. In a conversation with Claude Vannec in Hanoi, Ramèges, the director of the Institut Français, tries to dissuade the young man from undertaking an expedition into the jungle by emphasizing that two of the Institute's most valued members--a certain Odendh'al and a colleague named Henri Maître--had lost their lives during such incursions among the Moï (LP, p. 44). Subsequent historical investigation proved not only that these two individuals, Odendh'al and Maître, were extraordinary men who had led remarkable lives worthy of the legends related in the colonialists' "petites histoires", but that their activities had also made significant contributions to the establishment of the French presence in Indochina, contributions that were ultimately far more worthy than those of Mayrena, albeit somewhat less romanesque. Their stories are outside the scope of this essay, so we shall deal with them elsewhere.

In any case, when Malraux flies over the former colonies during his 1965 trip to Asia, he evokes with a certain sadness the ultimate fruitlessness of France's political adventure in that area: "Je survole la forêt, enchevêtrée comme au siècle dernier. L'administrateur [français] qui s'était voué aux Moïs a été chassé; aucun Vietnamien ne l'a remplacé. Les troupes françaises ont réoccupé--pour quoi faire?--les 'hauts plateaux sauvages'. Puis, elles sont parties" (A,p.379). But if--with great foresight--he had realized at the time of his 1928 revision of the initial version of LVR that the political dimensions he had originally envisaged for the novel were ephemeral, this was certainly not the case for the larger message that he eventually incorporated into the work. As he summed it up, again in the Antimémoires: "Le livre et le personnage [de Perken] sont nés [aussi] d'une méditation sur ce que l'homme peut contre la mort. D'où ce type de héros sans cause, prêt à risquer la torture pour la seule idée qu'il a de lui-même, et peut-être pour une sorte de saisie fulgurante de son destin-parce que le risque de la torture lui paraît seul vainqueur de la mort" (A, p. 379).

It is of course this element that remains most strikingly alive for those of us who read the novel today. However it is certainly not without interest to learn that as originally conceived LVR had a major political dimension as well, for this dimension provides an important indication of one of Malraux's personal commitments at the time of his return from Indochina--a commitment that quickly evolved into the passionate antifascism for which he is far better known. 


\section{NOTES}

1 For a detailed account of this expedition and its legal consequences, see in particular Walter G. Langlois, André Malraux: The Indochina Adventure (New York, 1966) pp. 3-51.

2 In our discussion, quotations from La Voie royale will be taken from the Livre de Poche edition, indicated by the abbreviation LP.

3 This manuscript is part of the Langlois-Ford Collection, and the quotations in the present essay are taken from the portions of that text to appear in volume I of the Pléïade edition of Malraux's works.

4 For background information on this important question, consult Pensri (Servanji) Duke, Les Relations étrangères entre la France et la Thaillande (Siam) (Bangkok, 1962); Likhit Dervegin, Siam and Colonialism, 1855-1909 (Bangkok, 1974); and Jeshurun Chandran, The Contest for Siam, 1889-1902: A Study in Diplomatic Rivalry (Kuala Lumpur, 1977).

5 Prince Chula Chakrabongse, The Twain Have Met: An Eastern Prince Came West (London, 1957), particularly pp. 57-67 and 111-115. The main details of this whole story are also confirmed by Malcolm Smith, who was Chulalongkorn's doctor at the time. See his A Physician at the Court of Siam (Oxford, 1953), especially pp. 115-116.

6 The original 1967 version of Malraux's Antimémoires contained the "Règne du malin" text (pp. 382-472), but it was cut from subsequent editions. In our essay we will quote from the definitive version of the Antimémoires that appeared as part of Le Miroir des limbes (Pléïade, 1972).

7 See, notably, Clara Malraux, Le Bruit de nos pas, III: Les Combats et les jeux (Paris, 1969), pp. 88-89.

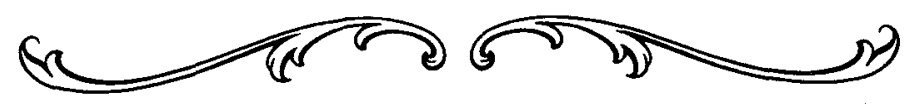

